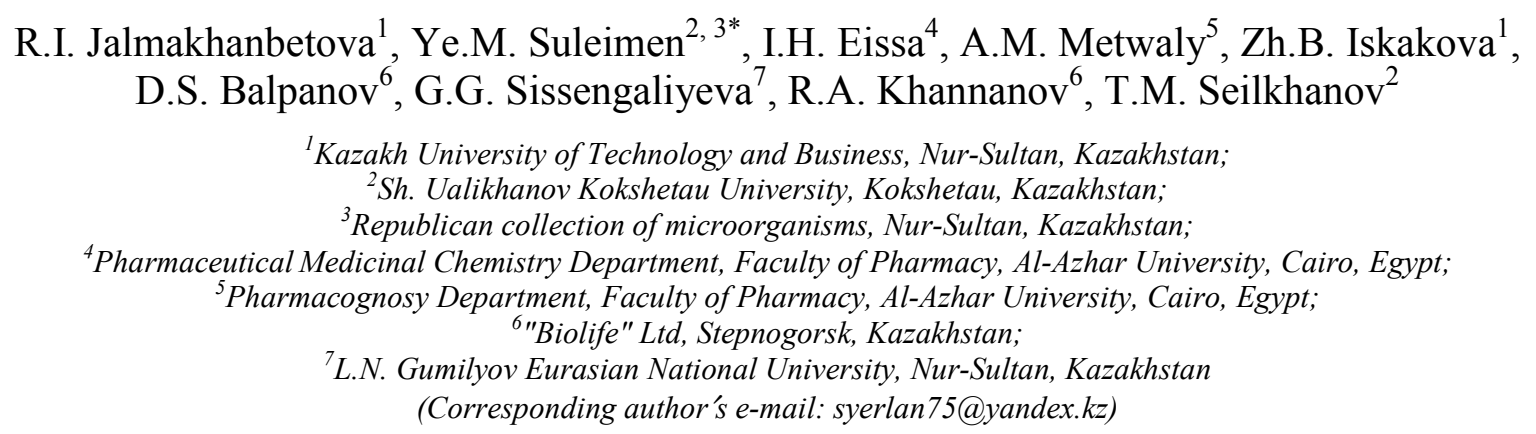

\title{
Isolation and biological evaluation of roseofungin and its cyclodextrin inclusion complexes
}

\begin{abstract}
Roseofungin belongs to polyene antibiotics which is more active and less toxic comparing other polyenes of this group. Roseofungin was isolated from Actinomyces roseoflavus var. Roseofungini using different chromatographic techniques and for the first time, the complexation of roseofungin with $\alpha$-, $\beta$ - and $\gamma$-cyclodextrin derivatives was performed. The binding patterns of the resulted complexes were studied in silico using molecular docking techniques. The best binding mode was for roseofungin against $\gamma$-CD with an affinity value of $-42.98 \mathrm{kcal} / \mathrm{mol}$. The proposed binding mode of roseofungin against $\alpha-\mathrm{CD}$ showed unusual interaction with an affinity value of $-41.80 \mathrm{kcal} / \mathrm{mol}$. Also, roseofungin bonded to $\beta-\mathrm{CD}$ with a binding affinity value of $-35.03 \mathrm{kcal} / \mathrm{mol}$. The antiradical and cytotoxic activities of roseofungin and its obtained $\alpha-, \beta$ - and $\gamma$-cyclodextrin complexes were determined. The antiradical activity was performed using butylhydroxyanisole as a reference, while the cytotoxic activity was determined using Artemia salina crustaceans. As a result of the biological activity study, it was found that roseofungin and some of its complexes have weak antiradical activities.
\end{abstract}

Keywords: roseofungin, cyclodextrin, in silico, molecular docking, complexation, antiradical activity, cytotoxicity.

\section{Introduction}

The development of modern industries and the rapid growth of the population in the past 50 years set the task of searching for new renewable resources: food sources, biofuels, medicines, cosmetics and hygiene products, which will undoubtedly lead to increased interest in natural renewable resources.

At the present time, the Republic of Kazakhstan does not have any its own drug that has antibacterial and anti-infective effect. The pharmaceutical industry of the Republic of Kazakhstan mainly produces galena preparations, as well as consumable medical devices such as masks, gloves, syringes, etc. The pharmaceutical and medical industry of the Republic of Kazakhstan has a big task to increase the share of domestic manufacturers in the market to $50 \%$ in the next 20 years. It is planned to modernize existing and build new pharmaceutical enterprises in the framework of the investment projects, to ensure the implementation of quality production standards in the pharmaceutical enterprises and to provide this industry with highly qualified staff.

In Kazakhstan, specialists of the Institute of Microbiology and Virology, al-Farabi Kazakh National University and South Kazakhstan state University named after M. Auezov are engaged in the search and study of new antibiotics, increasing the activity of produced known antibiotics. Thus, the broad-spectrum antifungal polyene antibiotic roseofungin was obtained for the treatment of deep and superficial mycoses. The spectrum of action of this antibiotic was found to be much broader than other known antifungal drugs $[1,2]$.

The antifungal ointment rosentein ${ }^{\circledR}$ is a roseofungin $2 \%$ ointment which was developed by the Institute of pharmaceutical biotechnology of the National Center of Biotechnology of the Republic of Kazakhstan [3]. The strong antiviral activity of roseofungin against influenza and parainfluenza viruses was proven before $[4,5]$.

From a chemical point of view, the roseofungin molecule is of great interest, since there are several reaction centers in the molecule that make it possible to obtain various derivatives. 
The relevance of this work lies in the lack of research and sufficient production of domestic antibiotics.

The purpose of the work was to obtain new derivatives of the antibiotic roseofungin and to study their physical, chemical and biological properties.

\section{Experimental}

\section{Isolation of roseofungin (1)}

An aqueous micelle (56.52 g) (the micelle was obtained from the culture fluid Actinomyces roseoflavus var. Roseofungini, Stepnogorsk, Kazakhstan) was treated twice with acetone. After that, the solution was filtered out using a vacuum pump. The resulting filtrate (acetone layer) was evaporated at $30-35^{\circ} \mathrm{C}$ on a rotary evaporator. The remaining concentrate (orange color) was extracted with $n$-butanol. Then the butanol layer was washed three times with $100,50,50 \mathrm{ml}$ of $1 \%$ aqueous solution of sodium hydroxide, and then twice with $100 \mathrm{ml}$ of water. After separation, the butanol layer was evaporated at $42{ }^{\circ} \mathrm{C}$ on a rotary evaporator. A precipitate was formed when $200 \mathrm{ml}$ of diethyl ether was added. The precipitate was filtered out in a vacuum. $0.71 \mathrm{~g}$ of raw roseofungin was obtained as a result. The mass was $0.69 \mathrm{~g}$ after drying in a vacuum concentrate. The roseofungin raw material was purified by gel filtration on Sephadex LH-20.

\section{Obtaining roseofungin / cyclodextrin complexes}

\subsection{Obtaining roseofungin complex with $\alpha$-cyclodextrin (2)}

$0.05 \mathrm{~g}$ of $\alpha$-cyclodextrin was placed in the crucible, a mixture of solvents $\left(\mathrm{C}_{2} \mathrm{H}_{5} \mathrm{OH}: \mathrm{H}_{2} \mathrm{O}, 1: 1\right)$ was added, and $0.05 \mathrm{~g}$ of roseofungin (1) was added. The reaction was performed for 2 hours. Then the suspension was left inside the desiccator overnight. After the obtained complex (2) was dried in vacuum to constant mass. The mass of the compound (2) was $0.07 \mathrm{~g}$, and the melting point was $210^{\circ} \mathrm{C}$ (decomp.). $\left.v, \mathrm{~cm}^{-1}\right)$.

The peaks of IR spectra were fixed at $696,777,1015,1148,1559,1653,2025,2159,2925,3351$ (neat,

\subsection{Obtaining roseofungin complex with $\beta$-cyclodextrin (3)}

$0.05 \mathrm{~g}$ of $\beta$-cyclodextrin was placed in the crucible, a mixture of solvents $\left(\mathrm{C}_{2} \mathrm{H}_{5} \mathrm{OH}: \mathrm{H}_{2} \mathrm{O}, 1: 1\right)$ was added, and $0.05 \mathrm{~g}$ of roseofungin (1) was added. The reaction was performed for 2 hours. Then the suspension was left inside the desiccator overnight. After the obtained complex (3) was dried in vacuum to constant mass. The mass of the compound (3) was $0.098 \mathrm{~g}$, and the melting point was $179{ }^{\circ} \mathrm{C}$ (decomp.).

The peaks of IR spectra were fixed at $668,695,777,795,1026,1419,1436,1457,1472,1507,1521$, $1540,1559,1636,1653,1684,1717,1734,2024,2158,2360,2922,3629,3649,3675,3744,3735,3853$ (neat, $v, \mathrm{~cm}^{-1}$ ).

\subsection{Obtaining roseofungin complex with $\gamma$-cyclodextrin (4)}

$0.05 \mathrm{~g}$ of $\alpha$-cyclodextrin was placed in the crucible, a mixture of solvents $\left(\mathrm{C}_{2} \mathrm{H}_{5} \mathrm{OH}: \mathrm{H}_{2} \mathrm{O}, 1: 1\right)$ was added, and $0.05 \mathrm{~g}$ of roseofungin (1) was added. The reaction was performed for 2 hours. The suspension was then left inside the desiccator overnight. After the obtained complex (4) was dried in vacuum to constant mass. The mass of the compound (4) was $0.13 \mathrm{~g}$, and the melting point was $200{ }^{\circ} \mathrm{C}$ (decomp.).

The peaks of IR spectra were fixed at $695,777,795,940,1023,1419,1457,1507,1521,1540,1559$, $1636,1653,1684,1700,1717,1734,2023,2159,2360,2925,3335,3629,3649,3675,3735,3744,3853$ (neat, $\mathrm{v}, \mathrm{cm}^{-1}$ ).

\section{Determination of antiradical activity}

$3 \mathrm{ml}$ of $6^{*} 10^{-5} \mathrm{M}$ radical solution was added to $0.1 \mathrm{ml}$ of the studied alcohol solutions in the concentration range of $0.1 ; 0.25 ; 0.5 ; 0.75$ and $1.0 \mathrm{mg} \mathrm{ml}^{-1}$ to determine the inhibition of 2,2-diphenyl-1-picrylhydrazyl radical (DPPH). The test tubes were in a tripod wrapped in black plastic. After intensive mixing, the solutions were left in the dark for 30 minutes, then the optical densities were measured at $520 \mathrm{~nm}$ wavelength. The antiradical activity (ARA) value of the studied objects were determined by the formula (1):

$$
\operatorname{APA}(\%)=\mathrm{A}_{0}-\mathrm{A}_{\mathrm{t}} / \mathrm{A}_{0} * 100
$$

where $A_{0}$ - is the optical density of the control sample; $A_{t}$ - is the optical density of the working sample.

The optical density of the studied compounds was measured at $520 \mathrm{~nm}$ using the Cary $60 \mathrm{UV}-\mathrm{Vis}$ device. The obtained antiradical activity was compared with the antiradical activity of butylhydroxyanisole (BHA) [6]. The optical density of the studied solutions, calculated by the formula 1, are shown in Table 1.

\section{Determination of cytotoxicity}

The cytotoxic activity was determined by a well-known method using Artemia salina crustaceans. Artemia is one of the standard organisms for testing the toxicity of chemical substances. 
The flask was filled with artificial seawater and $200 \mathrm{mg}$ of Artemia salina eggs were added. It was kept for 3 days with a soft supply of air, until the crustaceans were hatched from the eggs. One side of the tube was covered with aluminum foil, and 5 minutes later, the larvae that gather on the bright side of the flask were removed with a Pasteur pipette.

20-40 larvae were placed in $990 \mathrm{ml}$ of seawater in each of 30 test tubes. The number of dead larvae was counted under a microscope. $10 \mathrm{ml}$ of dimethylsulfoxide solution (DMSO) was added to $10 \mathrm{mg} \mathrm{ml}^{-1}$ of the sample. The test substance was used as a comparison drug. Only $10 \mathrm{ml}$ of DMSO was added for negative control. The number of dead larvae were counted under a microscope after 24 hours of incubation [7].

Mortality $\mathrm{P}$ was determined by the following formula (2):

$$
\mathrm{P}=(\mathrm{A}-\mathrm{N}-\mathrm{B}) / \mathrm{Z}^{*} 100 \text {, }
$$

where A - is the number of dead larvae after $24 \mathrm{~h} ; \mathrm{N}$ - is the number of dead larvae before the test; $\mathrm{B}$ - is the average number of dead larvae in negative control; $\mathrm{Z}$ - is the total number of larvae.

3 solutions were prepared with different concentrations of each substance.

\section{Docking studies}

\subsection{Preparation of the $\alpha-, \beta-$, and $\gamma$-cyclodextrin (CD) structure}

The 3D crystal structures of the $\alpha-, \beta$-, and $\gamma$-CD were extracted from the cyclo/maltodextrin/alphacyclodextrin complex, beta-amylase/ beta-cyclodextrin complex, and glycogen phosphorylase B/gamma cyclodextrin complex, respectively. These complexes were retrieved from RCSB Protein Data Bank with PDB IDs of 2ZYM (resolution 1.80 $\AA$ ), 1BFN (resolution $2.07 \AA$ ), and 1p2g (resolution $2.30 \AA$ ), respectively. The docking analyses were performed using Discovery Studio 4.0 software to evaluate the free energies and binding mode of roseofungin molecule with the core site of $\alpha-\beta-$, and $\gamma-\mathrm{CD}$. The most promising poses were selected depending the increased binding free energy $(\Delta G)[8-10]$.

The 3D crystal structures of $\alpha-, \beta$-, and $\gamma$-CD were prepared by selecting $\alpha, \beta$, and $\gamma$ CD subunits and removing protein and all water molecules, heteroatoms and co-factors. Moreover, the correction of uncorrected valence atoms and crystallographic disorders were performed using alternate conformations and valence monitor options. Then, the $\alpha-, \beta-$, and $\gamma$-CD were protonated and its inflexibility was obtained by creating fixed atom constraint. Next, the energy was minimized by applying CHARMM (Chemistry at HARvard Macromolecular Mechanics) force fields, and MMFF94 (Merck Molecular force field) force field for charge and partial charge, respectively [11]. The binding sites of the $\alpha-, \beta$-, and $\gamma-\mathrm{CD}$ were defined as receptor molecules and prepared for docking.

\subsection{Preparation of ligand}

The 2D structure of roseofungin molecule was sketched using ChemBioDraw Ultra 14.0 and saved in MDL-SD file format. Then, the SD file was opened (by Discovery studio 4.0 software) and protonated. Force fields were applied on the molecule to get lowest energy minimum structure via CHARMM and MMFF94 force fields for charge and partial charge, respectively. Then, each of them was prepared for docking by applying ligand preparation protocol.

\subsection{Docking simulation}

The docking is a technique that can reliably predict the preferred configuration of one molecule relative to another molecule when they are bound to each other to form a stable complex. The evaluation of generated poses was mainly based on the number of interactions they formed with the residues of active site upon binding [12-15].

The molecular docking of roseofungin was performed using CDOCKER protocol which is an implementation of the CDOCKER algorithm [16]. CDOCKER is a grid-based molecular docking method that employs CHARMM-based molecular dynamics (MD) scheme to dock ligands into a receptor binding site [17]. The default values were selected for the CDOCKER protocol. The CDOCKER energy (receptor-ligand interaction energy) of best docked poses was calculated $[18,19]$.

\section{Results and Discussion}

We worked out extracts of culture fluid and prepared a condensed extract. The antibiotic roseofungin was extracted twice from the wet mycelium with acetone under neutral reaction. The extracts were separated from the mycelium, combined, and the solvent was distilled in a vacuum. From the aqueous residue the antibiotic roseofungin was extracted with butanol.

Butanol extract was separated, washed several times first with sodium hydroxide, then with water. The extract was evaporated in vacuum and the antibiotic roseofungin was precipitated by diethyl ether. The sediment was filtered, washed with ether and dried in a vacuum. 
Subsequently, the roseofungin raw material was purified by gel filtration on Sephadex LH-20. Spirit eluates corresponding to the lemon-yellow zone were combined and stored in a vacuum. The sediment was filtered out, washed several times with ether, and dried. Amorphous lemon-yellow powder was obtained [20].

At the next stage of separation of the antibiotic roseofungin mixture, column chromatography was used, and the isolated fractions were once again purified by chromatography. The mixture of separated antibiotics was stored in an inert medium (argon) due to instability in light and air.

In order to obtain new derivatives, we carried out the complexation of roseofungin (1) with cyclodextrins. Cyclodextrins are macrocyclic compounds with a natural carbohydrate structure. Cyclodextrins contain molecules including a cylindrical plane.

It contains glucose residues connected by $\beta-1,4$-glycosidic bonds. Cyclodextrins differ depending on the number of monomers $\alpha-, \beta-, \gamma$ - and others. All the hydroxyl groups in the molecule are located on the outer surface of the molecule. Therefore, the inner cavity of cyclodextrins is hydrophobic.

Roseofungin (1) interacted with $\alpha$-cyclodextrin by the friction method. This is how the molecule (2) was formed. The compound (2) was powdery, with m.p. $210^{\circ} \mathrm{C}$ (decomp.).

Next, the roseofungin molecule (1) interacted with $\beta$-cyclodextrin. Compound (3) was obtained, it was powdery, with m.p. $179^{\circ} \mathrm{C}$ (decomp.).

Compound (4) was obtained as a result of the interaction of roseofungin with $\gamma$-cyclodextrin. The synthesized compound (4) was powdery, with m.p. $200^{\circ} \mathrm{C}$ (decomp.).

The optical density of the studied solutions, depending on the concentration, was measured on a spectrophotometer at the $520 \mathrm{~nm}$ wavelength. The optical density of the studied solutions, calculated by formula 1, are shown in Table 1.

T a b l e 1

Changes in the optical density of the studied solutions with changes in concentration

\begin{tabular}{|c|l|c|c|c|c|c|}
\hline \multirow{2}{*}{ No. } & \multirow{2}{*}{ Studied substances } & \multicolumn{5}{|c|}{ Optical density values by concentration $\left(\mathrm{mg} \mathrm{ml}^{-1}\right)$} \\
\cline { 3 - 7 } & & 0.1 & 0.25 & 0.5 & 0.75 & 1.0 \\
\hline 1 & Butylhydroxyanisole (BHA) & $0.1362 \pm 0.0000$ & $0.1333 \pm 0.0000$ & $0.1257 \pm 0.0000$ & $0.1202 \pm 0.0000$ & $0.1145 \pm 0.0000$ \\
\hline 2 & R-ACD (2) & $0.6485 \pm 0.0100$ & $0.6415 \pm 0.0000$ & $0.6481 \pm 0.0000$ & $0.6849 \pm 0.0000$ & $0.6849 \pm 0.0000$ \\
\hline 3 & R-BCD (3) & $0.7358 \pm 0.0000$ & $0.7550 \pm 0.0320$ & $0.7583 \pm 0.0000$ & $0.7601 \pm 0.0000$ & $0.7604 \pm 0.0000$ \\
\hline 4 & R-GCD (4) & $0.7335 \pm 0.0141$ & $0.7428 \pm 0.0000$ & $0.7577 \pm 0.0000$ & $0.7666 \pm 0.0000$ & $0.7665 \pm 0.0000$ \\
\hline 5 & Roseofungin (Roseof-1) (1) & $0.6364 \pm 0.0000$ & $0.6062 \pm 0.0000$ & $0.5781 \pm 0.0000$ & $0.5764 \pm 0.0223$ & $0.5631 \pm 0.0264$ \\
\hline
\end{tabular}

The antiradical activity of the studied solutions was compared with the antiradical activity of butylhydroxyanisole (BHA). The antiradical effect values of the studied extracts, calculated by the formula 1 , are shown in Table 2.

T a b l e 2

\section{Antiradical activity (\%) at different concentrations}

\begin{tabular}{|c|l|c|c|c|c|c|}
\hline \multirow{2}{*}{ No. } & \multirow{2}{*}{ Studied substances } & \multicolumn{5}{c|}{ Concentration $\left(\mathrm{mg} \mathrm{ml}^{-1}\right)$} \\
\cline { 3 - 7 } & & 0.1 & 0.25 & 0.5 & 0.75 & 1.0 \\
\hline 1 & Butylhydroxyanisole (BHA) & 80.82 & 81.23 & 82.30 & 83.08 & 83.88 \\
\hline 2 & R-ACD (2) & 12.03 & 12.98 & 12.09 & 7.09 & 7.09 \\
\hline 3 & R-BCD (3) & 8.97 & 6.59 & 6.19 & 5.96 & 5.93 \\
\hline 4 & R-GCD (4) & 9.26 & 8.10 & 6.26 & 5.16 & 5.17 \\
\hline 5 & Roseofungin (Roseof-1) (1) & 12.94 & 17.07 & 20.92 & 21.15 & 22.97 \\
\hline
\end{tabular}

The graphical dependence of the change in the studied substances antiradical activity on the change in concentration is shown in the Figure 1. 


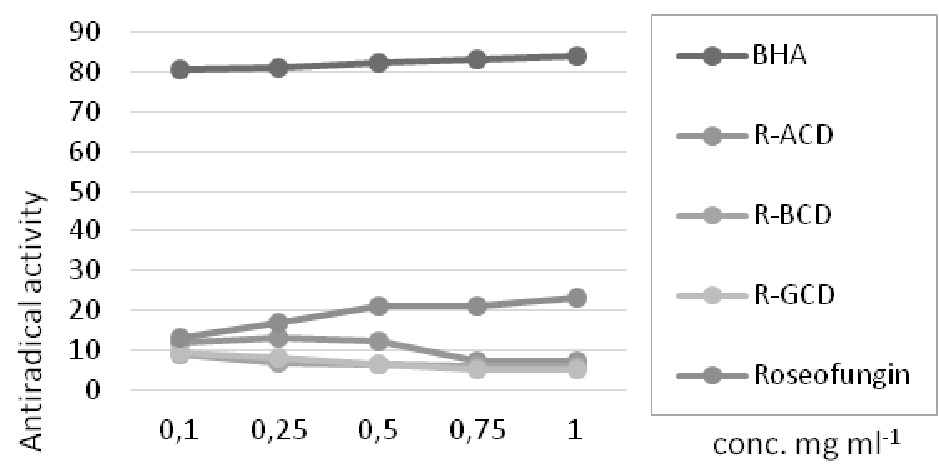

Figure 1. Dynamics of antiradical activity when the concentration of substances changes

Based on the analysis of data from tables and graphs, it can be seen that the substances R-ACD (2), R-BCD (3), R-GCD (4) and roseofungin (1) have very low antiradical activity compared to HPA.

The cytotoxic activity of the obtained complexes roseofungin $(2-4)$ was studied. The results of cytotoxic activity of roseofungin derivatives are presented in Table 3.

Table 3

\section{Results of cytotoxic activity of roseofungin derivatives}

\begin{tabular}{|c|c|c|c|c|c|c|c|c|c|c|}
\hline \multirow{2}{*}{$\begin{array}{l}\text { Test sub- } \\
\text { stances }\end{array}$} & \multirow{2}{*}{$\begin{array}{l}\text { Concen- } \\
\text { tration, } \\
\mathrm{mg} \mathrm{ml}^{-1}\end{array}$} & \multicolumn{2}{|c|}{$\begin{array}{c}\text { Number of lar- } \\
\text { vae in control }\end{array}$} & \multicolumn{3}{|c|}{$\begin{array}{c}\text { Number of larvae } \\
\text { in the sample }\end{array}$} & \multirow{2}{*}{$\begin{array}{c}\% \text { of sur- } \\
\text { viving lar- } \\
\text { vae in con- } \\
\text { trol }\end{array}$} & \multirow{2}{*}{$\begin{array}{c}\% \text { of surviv- } \\
\text { ing larvae in } \\
\text { the sample }\end{array}$} & \multirow{2}{*}{$\begin{array}{c}\text { Mortality, } \\
\text { A, } \%\end{array}$} & \multirow{2}{*}{$\begin{array}{c}\text { The presence of } \\
\text { neurotoxicity, } \\
\%\end{array}$} \\
\hline & & surv. & dead & surv. & dead & par. & & & & \\
\hline \multirow{3}{*}{$\mathrm{R}-\mathrm{ACD}(2)$} & 10 & $22 \pm 2.1$ & $1 \pm 0.0$ & $25 \pm 2.6$ & $1 \pm 0.7$ & $0 \pm 0.0$ & 96 & 96 & 0 & 0 \\
\hline & 5 & $22 \pm 2.1$ & $1 \pm 0.0$ & $23 \pm 1.6$ & $1 \pm 0.7$ & $0 \pm 0.0$ & 96 & 96 & 0 & 0 \\
\hline & 1 & $22 \pm 2.1$ & $1 \pm 0.0$ & $22 \pm 2.5$ & $0 \pm 0.0$ & $0 \pm 0.0$ & 96 & 96 & 0 & 0 \\
\hline \multirow{3}{*}{ R-BCD (3) } & 10 & $22 \pm 2.1$ & $1 \pm 0.0$ & $23 \pm 2.5$ & $1 \pm 1.0$ & $0 \pm 0.0$ & 96 & 96 & 0 & 0 \\
\hline & 5 & $22 \pm 2.1$ & $1 \pm 0.0$ & $25 \pm 2.1$ & $1 \pm 1.0$ & $0 \pm 0.0$ & 96 & 96 & 0 & 0 \\
\hline & 1 & $22 \pm 2.1$ & $1 \pm 0.0$ & $26 \pm 2.1$ & $1 \pm 0.7$ & $0 \pm 0.0$ & 96 & 96 & 0 & 0 \\
\hline \multirow{3}{*}{ R-GCD (4) } & 10 & $22 \pm 2.1$ & $1 \pm 0.0$ & $26 \pm 2.5$ & $3 \pm 1.6$ & $0 \pm 0.0$ & 96 & 89 & 7 & 0 \\
\hline & 5 & $22 \pm 2.1$ & $1 \pm 0.0$ & $21 \pm 1.7$ & $3 \pm 1.6$ & $0 \pm 0.0$ & 96 & 88 & 8 & 0 \\
\hline & 1 & $22 \pm 2.1$ & $1 \pm 0.0$ & $26 \pm 3.0$ & $2 \pm 2.1$ & $0 \pm 0.0$ & 96 & 93 & 3 & 0 \\
\hline
\end{tabular}

It can be assumed on the basis of conducted experiment, that complexes of cyclodextrins with roseofungin at all concentrations did not show cytotoxicity.

Docking technique was used to investigate the binding pattern of roseofungin with the $\alpha-, \beta-$, and $\gamma$-cyclodextrin. The $\alpha$-, $\beta$-, and $\gamma$-CD cavities are $\mathrm{O}$-shaped structures consisting of 6,7 , and 8 glucose unites, respectively.

Firstly, roseofungin exhibited ideal binding mode with $\beta$ - and $\gamma-\mathrm{CD}$, where roseofungin was buried inside the $\beta$ - and $\gamma-\mathrm{CD}$. These roseofungin involved in hydrogen bond network with glucose unites of $\beta$, and $\gamma$-CD. On the other hand, the binding mode of roseofungin against $\alpha \mathrm{CD}$ was unusual, where the $\alpha$-CD consists from 6 glucose subunits forming too small cavity to receive the bulk structure of roseofungin. While the cavities of both $\beta$ - and $\gamma$-CD were large enough to ingest roseofungin.

The proposed binding mode of roseofungin against $\alpha-C D$ revealed an affinity value of $-41.80 \mathrm{kcal} / \mathrm{mol}$. Although the good binding affinity, the binding mode was not good at all. The $\alpha$-CD was impeded inside the cavity of roseofungin, forming many interactions. Roseofungin has different hydroxyl and carbonyl groups which made eight hydrogen bonds with the different hydroxy groups of glucose subunits (Figures 2-8).

Contrastively, roseofungin bonded to $\beta-\mathrm{CD}$ with a binding affinity value of $-35.03 \mathrm{kcal} / \mathrm{mol}$. The roseofungin was impeded inside the cavity of $\beta-\mathrm{CD}$ and made several important interactions. The different hydroxyls and carbonyls of roseofungin made five hydrogen bonds with the hydroxyls of glucose subunits (Figures 9-15). 


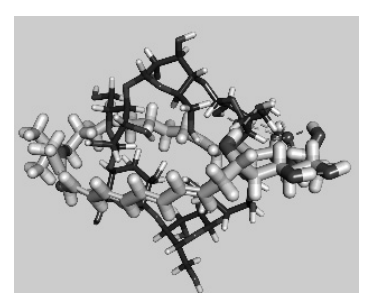

Figure 2. Docked pose of best ranked docking score of roseofungin (sticks) with $\alpha$-CD (sticks) (front view)

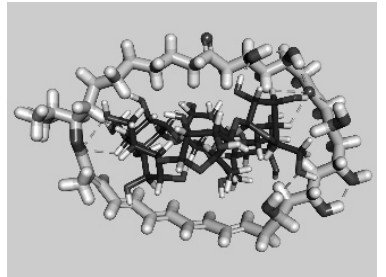

Figure 3. Docked pose of best ranked docking score of roseofungin (sticks) with $\alpha$-CD (sticks) (top view)

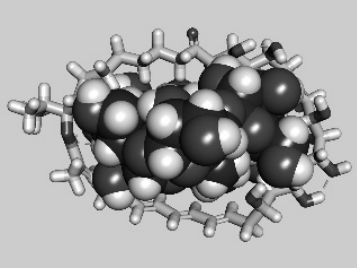

Figure 4. Docked pose of best ranked docking score of roseofungin (sticks) with $\alpha-\mathrm{CD}(\mathrm{CPK})$ (top view)

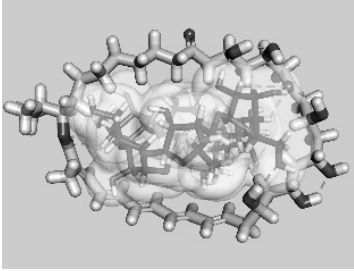

Figure 5. Surface view of $\alpha$-CD inside the cavity of roseofungin (top view)

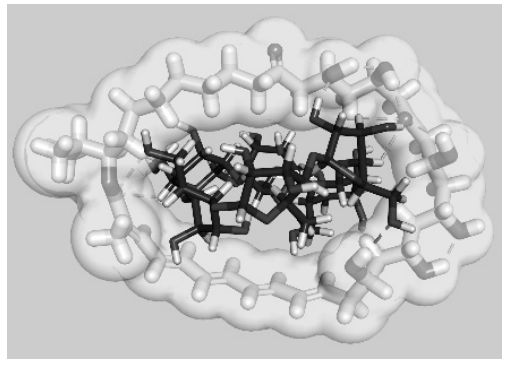

Figure 6. Surface view of $\alpha$-CD inside the cavity of roseofungin (top view)

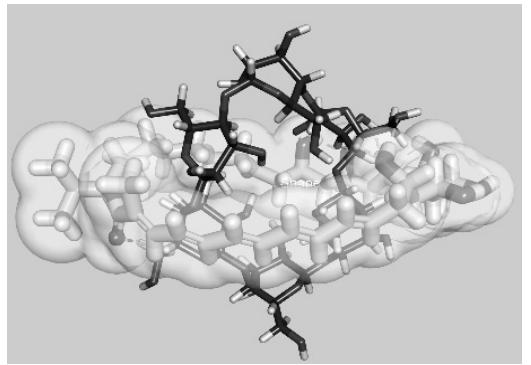

Figure 7. Surface view of $\alpha-C D$ inside the cavity of roseofungin (front view)

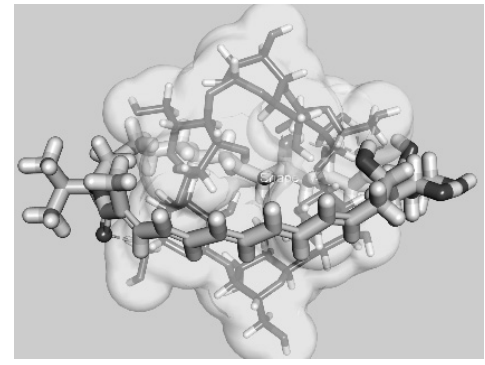

Figure 8. Surface view of $\alpha-C D$ inside the cavity of roseofungin (front view)

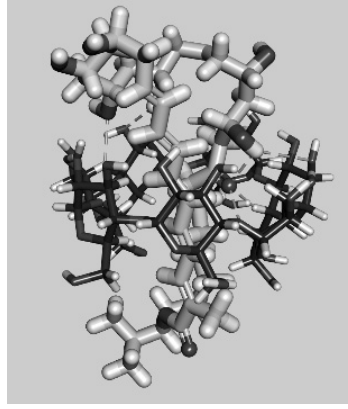

Figure 9. Docked pose of best ranked docking score of roseofungin (sticks) in the inner cavity of $\beta$-CD (sticks) (front view)

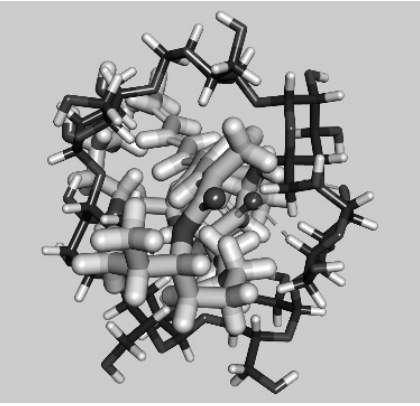

Figure 10. Docked pose of best ranked docking score of roseofungin (sticks) in the inner cavity of $\beta$-CD (sticks) (top view)

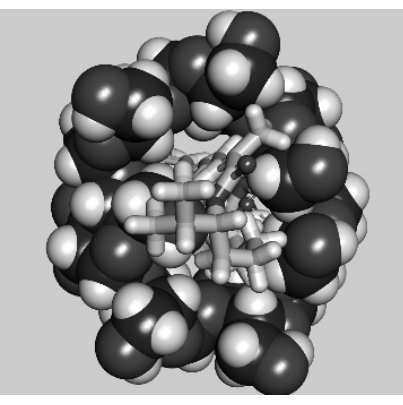

Figure 11. Docked pose of best ranked docking score of roseofungin (sticks) in the inner cavity of $\beta-C D(C P K)$ (top view)

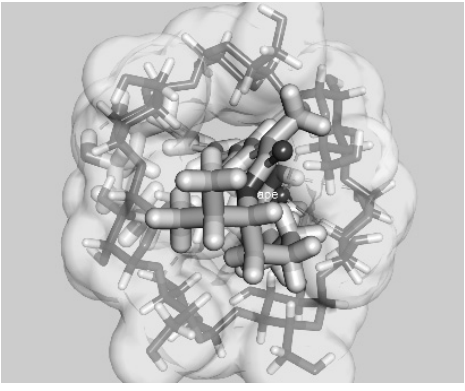

Figure 12. Surface view of roseofungin inside the cavity of $\beta-C D$ (top view)

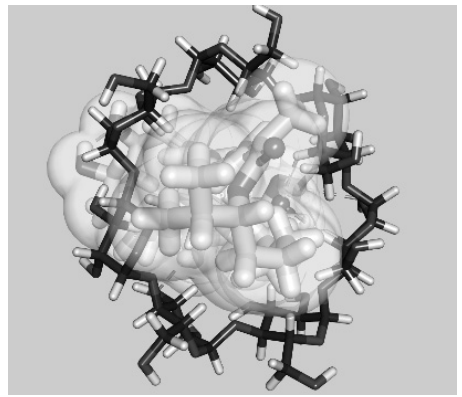

Figure 13. Surface view of roseofungin inside the cavity of $\beta-C D$ (top view)

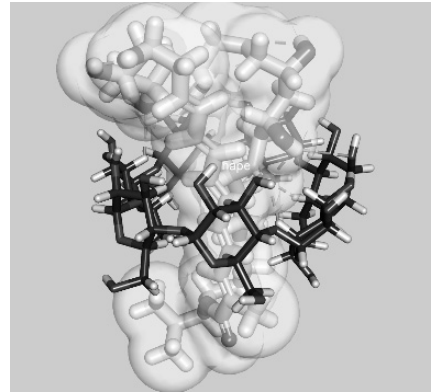

Figure 14. Surface view of roseofungin inside the cavity of $\beta$-CD (front view)

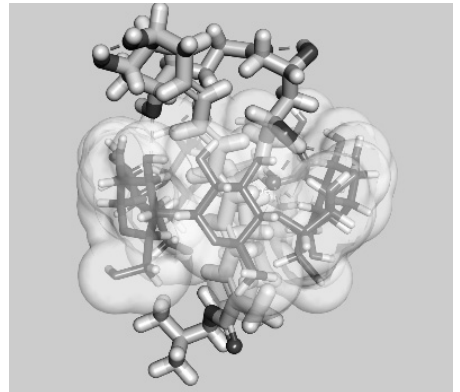

Figure 15. Surface view of roseofungin inside the cavity of $\beta-C D$ (front view) 
Fortunately, the expected binding mode of roseofungin against $\gamma$-CD was the best with an affinity value of --42.98 kcal $/ \mathrm{mol}$. The roseofungin was impeded perfectly inside the cavity of $\gamma-\mathrm{CD}$, forming many essential interactions. Roseofungin's hydroxyls and carbonyls could form ten hydrogen bonds with the hydroxyls of glucose subunits (Figures 16-22).

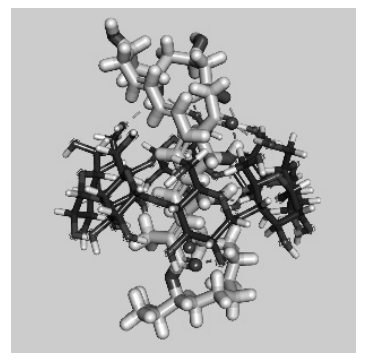

Figure 16. Docked pose of best ranked docking score of roseofungin (sticks) in the inner cavity of $\gamma$-CD (sticks) (front view)

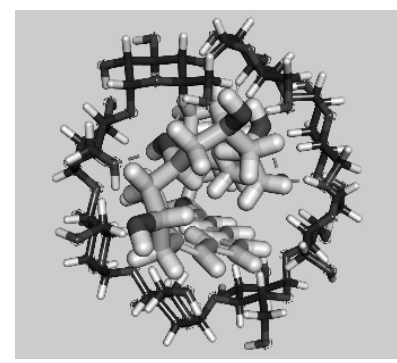

Figure 17. Docked pose of best ranked docking score of roseofungin (sticks) in the inner cavity of $\gamma$-CD (sticks) (top view)

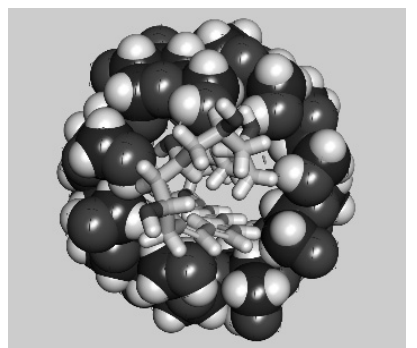

Figure 18. Docked pose of best ranked docking score of roseofungin (sticks) in the inner cavity of $\gamma-\mathrm{CD}(\mathrm{CPK})$ (top view)

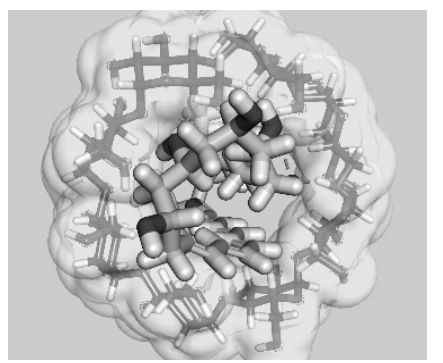

Figure 19. Surface view of roseofungin inside the cavity of $\gamma$-CD (top view)

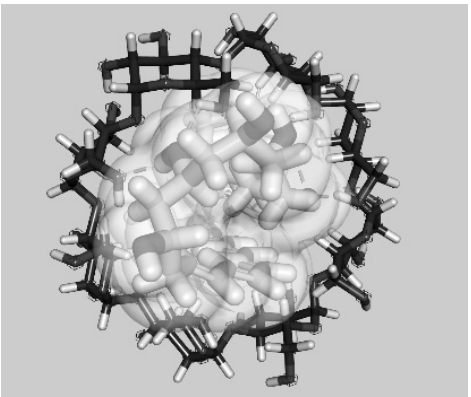

Figure 20. Surface view of roseofungin inside the cavity of $\gamma-\mathrm{CD}$ (top view)

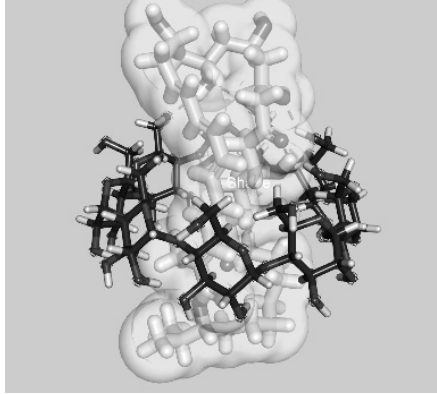

Figure 21. Surface view of roseofungin inside the cavity of $\gamma$-CD (front view)

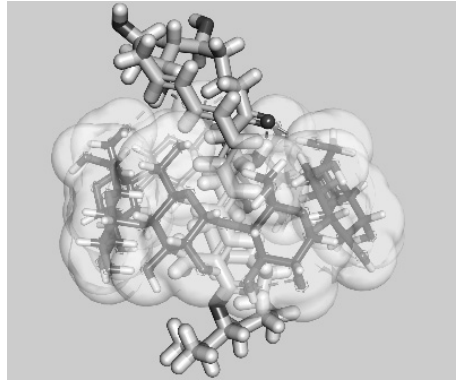

Figure 22. Surface view of roseofungin inside the cavity of $\gamma$-CD (front view)

This finding indicated that the binding of roseofungin with $\gamma$-CD is more advantageous.

\section{Conclusions}

Thus, roseofungin was isolated by chromatographic methods, also, its $\alpha$-, $\beta$-, and $\gamma$-cyclodextrin inclusion complexes were obtained. The results of the docking studies indicate that the complex of roseofungin with $\gamma$-CD is more advantageous. As a result of studying the biological activity, it was found that roseofungin and its cyclodextrin complexes have weak antiradical activity and not toxic.

\section{Acknowledgments}

This research has been funded by the Science Committee of the Ministry of Education and Science of the Republic of Kazakhstan (Grant No. AP 05130941).

\section{References}

1 Осипова Н.И. Ветеринарно-санитарная оценка продуктов животного происхождения, содержащих антибиотики / Н.И. Осипова // Ветеринария. Реф. журн. — 2010. — № 3. - С. 503.

2 Саубенова М.Г. Достижения Института микробиологии и вирусологии КН МОН РК / М.Г. Саубенова // Вестн. КазНУ. Сер. биол. - 2012. - № 4. - С. 6-8.

3 Waksman S.A. The species concept in relation to the Actinomycetes / S.A. Waksman // The Actinomycetes. Classification, Identification, and Description of Genera and Species, Waverly Press, Inc., Baltimore. — 1961. — Vol. 2. — P. 15-18. 
4 Шнейдер М.А. Вирусингибирующие свойства карбонил-конъюгированного пентаена розеофунгина / М.А. Шнейдер, Е.Б. Штильбанс, Л.А. Рачковская, Л.А. Ветлугина, Е.Т. Никитина // Антибиотики. — 2012. — Т. 29, № 5. — С. $344-349$.

5 Ермакова О.С. Антивирусные свойства пентаенового антибиотика розеофунгина / О.С. Ермакова, В.П. Толмачева, С.В. Левандовская, С.С. Худякова, А.П. Богоявленский, Н.Р. Махмудова и др. // Клиническая микробиология и антимикробная химиотерапия. - 2001. - № 3. - С. 13.

6 Suleimenov Ye.M. Components of Peusedanum morisonii and their antimicrobial and cytotoxic activity / Ye.M. Suleimenov // Chemistry of Natural Compounds. — 2009. — Vol. 45, No. 5. - P. 710-711.

7 Sawant O. In vitro free radical scavenging activity of Adiantum lunulatum / O. Sawant, V.J. Kadam, R. Ghosh // Journal of Herbal Medicine and Toxicology. — 2009. - Vol. 3, No. 2. — P. 39-44.

8 Ibrahim M.K. Design, synthesis, molecular modeling and anti-hyperglycemic evaluation of novel quinoxaline derivatives as potential PPAR $\gamma$ and SUR agonists / M.K. Ibrahim, et al. // Bioorganic \& medicinal chemistry. — 2017. — Vol. 25, No. 4. — P. 1496-1513.

9 Eissa I.H. Design and discovery of novel quinoxaline derivatives as dual DNA intercalators and topoisomerase II inhibitors / I.H. Eissa, et al. // Anti-Cancer Agents in Medicinal Chemistry (Formerly Current Medicinal Chemistry-Anti-Cancer Agents). 2018. - Vol. 18, No. 2. - P. 195-209.

10 Ibrahim M.K. Design, synthesis, molecular modeling and anti-hyperglycemic evaluation of quinazolin-4 (3H)-one derivatives as potential PPAR $\gamma$ and SUR agonists / M.K. Ibrahim, et al. // Bioorganic \& medicinal chemistry. — 2017. — Vol. 25, No. 17. — P. 4723-4744.

11 Roux B. CHARMM: the biomolecular simulation program / B. Roux, et al. // J Comput Chem. — 2009. — Vol. 30 , No. 10. - P. 1545614 Capriotti.

12 Elmetwally S.A. Design, synthesis and anticancer evaluation of thieno[2,3-d]pyrimidine derivatives as dual EGFR/HER2 inhibitors and apoptosis inducers / S.A. Elmetwally, et al. // Bioorganic chemistry. — 2019. — Vol. 88. — P. 102944.

13 Mahdy H.A. Design, synthesis, molecular modeling, in vivo studies and anticancer evaluation of quinazolin-4(3H)-one derivatives as potential VEGFR-2 inhibitors and apoptosis inducers / H.A. Mahdy, et al. // Bioorganic Chemistry. — 2020. - Vol. 94. - P. 103422.

14 El-Naggar A.M. Design, eco-friendly synthesis, molecular modeling and anticancer evaluation of thiazol-5(4H)-ones as potential tubulin polymerization inhibitors targeting the colchicine binding site / A.M. El-Naggar, et al. // RSC Advances. — 2020. — Vol. 10, No. 5. - P. 2791-2811.

15 Li N. Screening of Some Sulfonamide and Sulfonylurea Derivatives as Anti-Alzheimer's Agents Targeting BACE1 and PPAR $/$ N. Li, et al. // Journal of Chemistry. — 2020. — P. 19.

16 Li D.-D. Discovery of 6-substituted 4-anilinoquinazolines with dioxygenated rings as novel EGFR tyrosine kinase inhibitors / D.-D. Li, et al. // Bioorganic \& medicinal chemistry letters. — 2012. — Vol. 22, No. 18. — P. 5870-5875.

17 Sun J. Design, synthesis, biological evaluation, and molecular modeling study of 4-alkoxyquinazoline derivatives as potential VEGFR2 kinase inhibitors / J. Sun, et al. // Organic \& biomolecular chemistry. — 2013. — Vol. 11, No. 44. - P. 7676-7686.

18 El-Gamal K.M. Synthesis, docking, QSAR, ADMET and antimicrobial evaluation of new quinoline-3-carbonitrile derivatives as potential DNA-gyrase inhibitors / K.M. El-Gamal, et al. // Journal of Molecular Structure. — 2018. — Vol. 1166. — P. 1533.

19 Ibrahim, M., et al. (2018). Design, synthesis, molecular modeling and anti-proliferative evaluation of novel quinoxaline derivatives as potential DNA intercalators and topoisomerase II inhibitors / M. Ibrahim, et al. // European journal of medicinal chemistry. - Vol. 155. - P. 117-134.

20 Sadanov A.K. Isolation and characterization of "brown impurity" accompanying the antibiotic rozeofungin / A.K. Sadanov, A.S. Balgimbaeva, L.P. Trenozhnikova, V.E. Berezin // News of the national academy of sciences of the Republic of Kazakhstan. Series: biological and medical. - 2015. - No. 2. - C. 97-100.

\section{Р.И. Жалмаханбетова, Е.М. Сүлеймен, И.Х. Эйса, А.М. Метуали, Ж.Б. Искакова, Д.С. Балпанов, Г.Ғ. Сисенғалиева, Р.А. Ханнанов, Т.М. Сейлханов}

\section{Розеофунгинді оқшаулау және биологиялық бағалау және оның циклодекстринді енгізу кешендері}

Розеофунгин полиен антибиотиктеріне жатады, ол осы топтың басқа полиендерімен салыстырғанда
белсенді және аз уытты. Розеофунгин әр түрлі хроматографиялық әдістерді қолдана отырып
Actinomyces roseoflavus var Roseofungini-ден оқшауланған және алғаш рет $\alpha$-, $\beta$ - және $\gamma$-циклодекстрин
туындыларымен розеофунгиннің кешенді түзілуі жүргізілді. Алынған кешендердің байланыстыру
заңдылықтары in silico молекулалық докинг әдістерін қолдана отырып зерттелді. Ең жақсы
байланыстыру режимі-42,98 ккал/моль жақындық мәні бар $\gamma$-CD-ге қарсы розеофунгин үшін болды.
Розеофунгинді $\alpha$-CD-мен байланыстырудың ұсынылған әдісі жақындық мәні -41,80 ккал/моль
болатын ерекше әрекеттесуді көрсеті. Сонымен қатар, розеофунгин $\beta$-CD-мен байланыстың
жақындық мәні -35,03 ккал/моль арқылы байланысады. Розеофунгиннің және оның алынған $\alpha$-, $\beta$ - 
және $\gamma$-циклодекстринді кешендерінің радикалға қарсы және цитоуыттылық белсенділігі анықталды. Радикалға қарсы белсенділік эталон ретінде бутилгидроксианизолды қолдану арқылы жүргізілді, ал цитоуыттылық белсенділік Artemia salina шаян тәрізділерді қолдану арқылы табылды. Биологиялық белсенділікті зерттеу нәтижесінде розеофунгиннің және оның кейбір кешендерінің әлсіз антирадикалды белсенділігі бар екендігі анықталды.

Кiлm сөздер: розеофунгин, циклодекстрин, in silico, молекулалық докинг, комплекс түзілу, антирадикалды белсенділік, цитоуыттылық.

\title{
Р.И. Джалмаханбетова, Е.М. Сулеймен, И.Х. Эйса, А.М. Метуали, Ж.Б. Искакова, Д.С. Балпанов, Г.Г. Сисенгалиева, Р.А. Ханнанов, Т.М. Сейлханов
}

\section{Выделение и биологическая оценка розеофунгина и его циклодекстриновые комплексы включения}

\begin{abstract}
Розеофунгин относится к полиеновым антибиотикам и является более активным и менее токсичным по сравнению с другими полиенами этой группы. Розеофунгин был выделен из Actinomyces roseoflavus var. Roseofungini с использованием различных хроматографических методов. Авторами впервые было проведено комплексообразование розеофунгина с производными $\alpha$-, $\beta$ - и $\gamma$-циклодекстрина. Паттерны связывания полученных комплексов были изучены in silico с использованием методов молекулярного докинга. Наилучший режим связывания был для розеофунгина против $\gamma$-CD со значением аффинности $-42,98$ ккал/моль. Предложенный способ связывания розеофунгина с $\alpha-\mathrm{CD}$ показал необычное взаимодействие со значением аффинности $-41,80$ ккал/моль. Кроме того, розеофунгин связывается с $\beta$ CD со значением аффинности связывания $-35,03$ ккал/моль. Определена антирадикальная и цитотоксическая активность розеофунгина и полученных его $\alpha$-, $\beta$ - и $\gamma$-циклодекстриновых комплексов. Антирадикальную активность определяли используя в качестве эталона бутилгидроксианизол, а цитотоксическую активность - на ракообразных Artemia salina. В результате исследования биологической активности было установлено, что розеофунгин и некоторые его комплексы обладают слабой антирадикальной активностью.
\end{abstract}

Ключевые слова: розеофунгин, циклодекстрин, in silico, молекулярный докинг, комплексообразование, антирадикальная активность, цитотоксичность.

\section{References}

1 Osipova, N.I. (2010). Veterinarno-sanitarnaia otsenka produktov zhivotnoho proiskhozhdeniia, soderzhashchikh antibiotiki [Veterinary and sanitary assessment of animal products containing antibiotics]. Veterinariia. Referativnyi zhurnal — Veterinary. Abstract journal, 3, 503 [in Russian].

2 Saubenova, M.G. (2012). Dostizheniia Instituta mikrobiolohii i virusolohii KN MON RK [Achievements of the Institute of Microbiology and Virology SC MES RK]. Vestnik Kazakhskoho natsionalnoho universiteta. Seriia biolohicheskaia - Bulletin of Kazakh National University. Biological series, 4, 6-8 [in Russian].

3 Waksman, S.A. (1961). The species concept in relation to the Actinomycetes. The Actinomycetes. Classification, Identification, and Description of Genera and Species, (Vol. 2). Waverly Press, Inc., Baltimore.

4 Shneider, M.A. (2012). Virusinhibiruiushchie svoistva karbonil-koniuhirovannoho pentaena rozeofunhina [Verosimilitudes properties of the carbonyl-conjugated pentaen of roseofungin]. Antibiotiki - Antibiotics, 29(5), 344-349 [in Russian].

5 Ermakova, O.S., Tolmacheva, V.P., Levandovskaya, S.V., Hudyakova, S.S., Bogoyavlenskij, A.P., \& Mahmudova, N.R., et al. (2001). Antivirusnye svoistva pentaenovoho antibiotika rozeofunhina [Antiviral properties of the pentaenotic roseofungin]. Klinicheskaia mikrobiolohiia i antimikrobnaia khimioterapiia — Clinical Microbiology and antimicrobial chemotherapy, 3, 13 [in Russian].

6 Suleimenov, Ye.M. (2009). Components of Peusedanum morisonii and their antimicrobial and cytotoxic activity. Chemistry of Natural Compounds, 45(5), 710-711.

7 Sawant, O., Kadam, V.J., \& Ghosh, R. (2009). In vitro free radical scavenging activity of Adiantum lunulatum. Journal of Herbal Medicine and Toxicology, 3(2), 39-44.

8 Ibrahim, M.K., et al. (2017). Design, synthesis, molecular modeling and anti-hyperglycemic evaluation of novel quinoxaline derivatives as potential PPAR $\gamma$ and SUR agonists. Bioorganic \& medicinal chemistry, 25(4), 1496-1513.

9 Eissa, I.H., et al. (2018). Design and discovery of novel quinoxaline derivatives as dual DNA intercalators and topoisomerase II inhibitors. Anti-Cancer Agents in Medicinal Chemistry (Formerly Current Medicinal Chemistry-Anti-Cancer Agents), 18(2), 195209.

10 Ibrahim, M.K., et al. (2017). Design, synthesis, molecular modeling and anti-hyperglycemic evaluation of quinazolin-4(3H)one derivatives as potential PPAR $\gamma$ and SUR agonists. Bioorganic \& medicinal chemistry, 25(17), 4723-4744. 
11 Roux, B., et al. (2009). CHARMM: the biomolecular simulation program. J Comput Chem, 30(10), 1545614 Capriotti.

12 Elmetwally, S.A., et al. (2019). Design, synthesis and anticancer evaluation of thieno[2,3-d]pyrimidine derivatives as dual EGFR/HER2 inhibitors and apoptosis inducers. Bioorganic chemistry, 88, 102944.

13 Mahdy, H.A., et al. (2020). Design, synthesis, molecular modeling, in vivo studies and anticancer evaluation of quinazolin4(3H)-one derivatives as potential VEGFR-2 inhibitors and apoptosis inducers. Bioorganic Chemistry, 94, 103422.

14 El-Naggar, A.M., et al. (2020). Design, eco-friendly synthesis, molecular modeling and anticancer evaluation of thiazol$5(4 \mathrm{H})$-ones as potential tubulin polymerization inhibitors targeting the colchicine binding site. RSC Advances, 10(5), $2791-2811$.

$15 \mathrm{Li}$, N., et al. (2020). Screening of Some Sulfonamide and Sulfonylurea Derivatives as Anti-Alzheimer's Agents Targeting BACE1 and PPAR $\gamma$. Journal of Chemistry, 19.

16 Li, D.-D., et al. (2012). Discovery of 6-substituted 4-anilinoquinazolines with dioxygenated rings as novel EGFR tyrosine kinase inhibitors. Bioorganic \& medicinal chemistry letters, 22(18), 5870-5875.

17 Sun, J., et al. (2013). Design, synthesis, biological evaluation, and molecular modeling study of 4-alkoxyquinazoline derivatives as potential VEGFR2 kinase inhibitors. Organic \& biomolecular chemistry, 11(44), 7676-7686.

18 El-Gamal, K.M., et al. (2018). Synthesis, docking, QSAR, ADMET and antimicrobial evaluation of new quinoline-3carbonitrile derivatives as potential DNA-gyrase inhibitors. Journal of Molecular Structure, 1166, 15-33.

19 Ibrahim, M., et al. (2018). Design, synthesis, molecular modeling and anti-proliferative evaluation of novel quinoxaline derivatives as potential DNA intercalators and topoisomerase II inhibitors. European journal of medicinal chemistry, 155, $117-134$.

20 Sadanov, A.K., Balgimbaeva, A.S., Trenozhnikova, L.P., \& Berezin, V.E. (2015). Isolation and characterization of "brown impurity" accompanying the antibiotic rozeofungin. News of the national academy of sciences of the Republic of Kazakhstan. Series: biological and medical, 2, 97-100.

\section{Information about authors}

Jalmakhanbetova, Roza Ilemisovna - Doctor of chemical sciences, Kazakh University of Technology and Business, Nur-Sultan, K. Mukhamedkhanov Str., 37A, Kazakhstan; e-mail: rozadichem@mail.ru, ORCID: 0000-0001-9937-275X.

Suleimen, Yerlan Melsuly - Candidate of chemical sciences, $\mathrm{PhD}, 1)$ Senior researcher of the laboratory of Engineering Profile of NMR Spectroscopy, Sh. Ualikhanov Kokshetau university, Kokshetau, Abay street, 76, 020000, Kazakhstan; 2) Main Scientific Secretary of Republican collection of microorganisms, Nur-Sultan, Sh. Ualikhanov 13/1,010000, Kazakhstan; e-mail: syerlan75@yandex.kz, ORCID 00000002-5959-4013.

Eissa, Ibrahim Hasan - Associate professor, Pharmaceutical Medicinal Chemistry \& Drug Design Department, Faculty of Pharmacy (Boys), Al-Azhar University, Cairo11884, Egypt; e-mail: ibrahimeissa@azhar.edu.eg, ORCID 0000-0002-6955-2263.

Metwaly, Ahmed Mohamed - Associate professor, Pharmacognosy Department, Faculty of Pharmacy (Boys), Al-Azhar University, Cairo11884, Egypt; e-mail: ametwaly@azhar.edu.eg, ORCID 0000-00018566-1980.

Iskakova, Zhanar Baktybaevna - Candidate of chemical sciences, Kazakh University of Technology and Business, Nur-Sultan, K. Mukhamedkhanov Str., 37A, Kazakhstan; e-mail: zhanariskakova@mail.ru; https://orcid.org/0000-0002-3540-8263.

Balpanov, Darhan Serikovich - Candidate of chemical sciences, research associate of "Biolife" Ltd, Stepnogorsk, 5 district, 8-80, Kazakhstan; e-mail: balpan@mail.ru.

Sissengaliyeva, Gulsana Galimzhankyzy - L.N. Gumilyov Eurasian National University, Satpaev street, 2, 010000, Nur-Sultan, Kazakhstan; e-mail: sissengaliyevag@gmail.com, ORCID: 0000-0002-90-1704.

Khannanov, Rinat Ashatovich - master's degree, Director of "Biolife" Ltd, Stepnogorsk, 5 district, 8-80, Kazakhstan; e-mail: khanrinat@yandex.ru, ORCID ID 0000-0001-5085-7596.

Seilkhanov, Tulegen Muratovich - Candidate of chemical science, full professor, Head of the laboratory of Engineering Profile of NMR Spectroscopy, Sh. Ualikhanov Kokshetau university, Kokshetau, Abay street, 76, 020000, Kazakhstan, e-mail: tseilkhanov@mail.ru, ORCID ID 0000-0003-0079-4755. 